\title{
Sustainability: The train has left the station
}

Ritchie D. Priddy, Baton Rouge, Louisiana 70820

Address all correspondence to Ritchie D. Priddy at rdpriddy@gmail.com

(Received 31 January 2017; accepted 10 March 2017)

\section{ABSTRACT}

The sustainability movement has more influence over company and government climate change actions than any treaty, law or regulation could possibly have, and results in quicker, measurable actions.

The sustainability movement is alive and well, and will continue to grow despite the outcry over some countries backpedaling from the Paris Accord. When one stops to consider just how much action companies from around the world have taken toward sustainability one cannot help but be amazed that so much was done without treaties, laws and regulations to force compliance. The primary driver of action is peer pressure - that which is derived from the actions of industry, and not the actions of government. This movement, found under a company's corporate social responsibility (CSR) banner, will continue to grow by virtue of the continuous adoption of sustainability reporting, and in particular, supply chain reporting, benchmarking and risk management practices of industry, and the adoption of energy efficient (EE) projects. These actions have already resulted in significant positive changes to private company and government behavior, company value, lower emissions, greater operational efficiency, and competitive advantage. One could argue that peer pressure is much more effective than any treaty, laws, or regulations could possibly be. But, it should be noted that the term "climate change" remains a contentious issue and companies would be wise to refer to all related actions as sustainability.

Keywords: government policy and funding; sustainability; environment

\section{DISCUSSION POINTS}

- Despite lack of binding treaties and clear direction corporations are taking measureable steps to curb emissions in response to several diverse drivers, and this will continue regardless of which party or government is in power.

- CC mitigation efforts, including reporting, have led to a level of growth in energy efficiency (EE) project adoption—which remains the most effective and measureable step that can be taken to reduce emissions, reduce energy usage, and encourage efficiency that the world has seen.

- The primary reason for reporting, and thus, EE action, boils down to peer pressure, which has far more influence on compliance than any treaty could.

In his article in this month's journal ("Climate change and fossil fuel: an examination of risks for the energy industry and producer states"), Jim Krane, of the Baker Institute, examined the climate change risks for the energy industry and producer states. A former journalist himself, Krane's approach to this important issue was balanced, and more thorough than most articles on the impact of climate change on the energy industry.
He also correctly pointed out a new set of risks facing the energy industry. As a former journalist myself, I appreciate Jim's curiosity, his investigative work, and agree with the majority of his findings. When the reader ties in the takeaways from M.J. Kelly's excellent article "Lessons from technology development for energy and sustainability" in Volume 3, 2016 issue of this journal, ${ }^{1}$ that the decarbonization efforts to date will fall woefully short of what is needed by mid-century, and that the disruptive technologies that must be used to make meaningful headway in meeting climate objectives have not been invented yet, one begins to realize the enormity of what lies ahead for every segment of society, and in a short period of time (by mid-century), if we are to avoid what many believe to be catastrophic climate damage.

I won't dive into the climate risks of energy producing companies and states that Krane identifies other than to provide the reader a look at the climate change $(\mathrm{CC})$ issue from another angle that most people rarely see-that of the end-use energy consumer, particularly medium to large nonenergy producing corporations who spend millions of dollars annually on power purchases to conduct their operations and produce and deliver their goods. While at one of the largest retail electric providers (REPs) in the U.S., I worked closely with many of our largest customers on these issue, often with multistate sites. For those 
companies located in states with choice (i.e., deregulated) they could leave their provider for a lower price or better service. In a highly competitive market where the margins were continuously shrinking, a REP had better provide the best service for the best price. [Note: the natural gas market is nowhere near as deregulated for end-use consumers.]

All of these companies have climate concerns, each have specific interests and beliefs, and many of these companies naturally turned to their energy suppliers for help, and often advice, in dealing with an issue that is certainly contentious and often contradictory. This article describes some of my experiences and are a microcosm of what is happening in the sustainability realm.

For clarification purposes it is necessary for me to distinguish between climate change and sustainability. According to the Environmental Protection Agency (EPA), climate change (CC) refers to any significant change in the measures of climate lasting for an extended period of time. In other words, climate change includes major changes in temperature (i.e., global warming), precipitation, or wind patterns, among other effects, that occur over several decades or longer. ${ }^{2}$

I don't know anyone who disagrees that the climate is changing. It always has, and always will. The argument is over mankind's impact on such change. That has become a contentious political and, some say, a religious issue that will not be solved any time soon, and is not the point of this article. I have found it to be a polarizing issue, and care should be taken when addressing it. Despite the controversy surrounding CC, it has become so ingrained in today's world that no one can ignore it. Every company must address it, and they are, which brings me to sustainability.

"Sustainability-an approach to business that creates long-term stakeholder value by embracing opportunities and managing risks deriving from economic, environmental, and social developments." 3

So, sustainability is a response that companies take to maximize opportunities while managing risks (economic, environmental, and social) that lead to long-term shareholder value. In the context of this article, sustainability is the response companies take to the threat of climate change without actually having to refer to it.

The sustainability definition above stems from the 1987 Brundtland Commission (the UN World Commission on Environment and Development (WCED)). It is hardly extremist or threatening. The three pillars of sustainability (economic, environmental, and social) were further defined by the 2005 World Summit on Social Development. ${ }^{4}$ This has led to what I refer to as the greatest accomplishment CC advocates have ever made: their ability to seize upon this and irrevocably tie sustainability into Corporate Social Responsibility (CSR). It was brilliant and continues to serve their cause well!

Any one who has read any of my work or has heard me speak ( $>200$ articles and presentations) knows that I believe that the sustainability train has left the station, and it's not coming back. Sure, many believe that it's entered some rough times, and the pace may slow, but I believe the evidence is overwhelming that sustainability actions will continue around the world regardless who, or what types of governments, are in place. It is my opinion that this movement is so powerful that no legally-binding treaty can come close to having as much authority or influence in reducing emissions, lowering energy use, and increasing operational efficiency.

A few key takeaways from my experiences with these large end-users:

(i) Despite the lack of certainty, and lack of direction from governments (legally binding international treaties, inconsistent and often contradictory regulations, and more), companies around the world are taking actions to lower their carbon emissions, reduce energy consumption and adopt cleaner, more sustainable, operations. This is truly remarkable when one considers these actions have largely been voluntary;

(ii) Companies are run by pretty smart people with little time to adequately explore the external environment or gather and evaluate all the relevant data needed to make decisions about things outside their core capabilities or markets. On major issues outside their expertize most will follow their peers, or seek best practices on those issues. The influence of peer pressure forcing actions cannot be overstated regardless of the issue-especially with $C C$.

(iii) They are quite aware of the extremist and polarizing arguments related to CC. Both of those views are-more often than not-reflected internally somewhere along the decision chain. Many companies recognize that the term $C C$ itself is a red-flag term and should be avoided;

(iv) Customers and shareholders are demanding action. The business case for taking action is becoming more obvious and accepted by boardrooms. Many companies place the actions they take under the CSR (described above), triple-bottom line (an accounting framework that focuses on a company's social, environmental, and financial impact), sustainability or some similar banner for outside consumption. But, it clearly is being viewed internally as risk management with a positive spin for public consumption.

(v) While companies plan for the long term, the short term (i.e., quarterly and annual reports) most often takes precedence. Boards have a fiduciary responsibility to their shareholders to maximize returns and to operate as efficiently as possible while striving to meet their CSR goals;

(vi) Energy purchasing departments are almost universally separate from sustainability departments, which is separate from their risk management departments. Each has different objectives-and they rarely talk!

I have found that the communications problem is serious, and goes much deeper than that between the sustainability office and the energy buyer. Most of the customers I engaged with had multiple people assigned to their energy purchasing 
department, each typically responsible for buying energy for a specific geographic area. Some, in fact, had purchasing offices located in multiple states. The sustainability department was almost universally found at company headquarters with few staffers. Not only did they not communicate, they rarely seemed to realize the other existed. That's senior management's fault, and there is no excuse for it. Formalizing a sustainability plan must come from above and include staff from every department impacted, if for no other reason other than compensation plans-specifically bonuses. Energy purchasers for large companies are typically paid a salary plus bonus. If the buyers are good negotiators, or just plain lucky (i.e., great timing when they purchase energy), and they save their companies substantial money their bonuses will be good to very good.

This struck home to me when I was at an energy conference and a client's energy buyer was present. His corporate sustainability person was also present. I don't think either was aware of the other's presence. The buyer pulled me aside and told me that his bonus was in jeopardy because the sustainability person wanted to count the money saved via his (the buyer's) negotiation skill as the fulfillment of company sustainability objectives. Who wins such an argument? I don't know, but I know who should.

\section{Introduction}

I'll address these takeaways throughout this article, with a focus on what I found to be the primary drivers of corporate action on sustainability.

Energy is in every company's supply chain. Since much of my experience is directly related to energy buyers and sustainability departments I'll focus this perspective on what I have learned from those interactions.

As I stated, CC is a contentious issue. I found early on just how contentious it is. I often accompanied our large volume sales representatives on sales calls to answer any questions on sustainability. On one particular occasion I made the mistake of mentioning climate change by name. His response: "if you mention climate change one more time you're out the door." That company purchased millions of dollars worth of electricity from us every year. In a highly competitive market where electricity is distinguished only by price, and the margins are very low (and shrinking), you cannot afford to take a side. It was then that I began to use the term "sustainability." People love to hate energy companies. I don't think that will ever change. Best for an energy person to stay firmly in the middle on this argument, especially.

\section{Why do corporations take action relating to climate change?}

Krane addressed a lot of the risks (and drivers) that fossil fuel companies face with climate change. There is a great deal of overlap with all companies so I won't dwell on them, except to point out that at the end of the day it boils down to risk management. I think that aspect alone makes this issue so unique. History shows that in uncertain times, or the absence of clear market signals/information/direction, there is little investment, and few actions are taken concerning a huge unknown. Why then, have so many companies taken sustainability actions? I believe the answer is clear-companies must manage risk-especially unknown risks based largely on the drivers I outline below.

No company can afford not to take action, even without a clear direction. And, it is not lost on companies that action can be profitable, and not only in the way of cost reductions and efficiency improvements, but in terms of stock price, corporate goodwill, and even competitive advantage. So, the companies who have embraced sustainability have taken a negative (i.e., CC and the unknown impact it may have on their business) and turned it into a positive by taking a proactive approach that results in concrete actions such as annual sustainability reporting (which positively portrays a company's action in the social, environmental, and business realms).

I spent a lot of time with customers, and I asked a lot of questions. And, I listened. The graphic below lists what I found to be the primary drivers of corporate action (Fig. 1). There are subsets of these drivers, some of which are just emerging. All are interrelated. Much of the information available for corporate planners is misleading and biased. I don't have room here to go into much detail on any of them, but I have included a brief description of each, including the key lessons I've learned from those interactions.

\section{Drivers}

\section{Political}

There is no overarching legally-binding international or national political consensus regarding CC. The Paris Agreement "aims to strengthen the global response to the threat of climate change in the context of sustainable development and efforts to eradicate poverty, including by: (i) holding the increase in the global average temperature to well below $2{ }^{\circ} \mathrm{C}$ above preindustrial levels and pursuing efforts to limit the temperature increase to $1.5{ }^{\circ} \mathrm{C}$ above preindustrial levels,

\section{What's driving all this?}

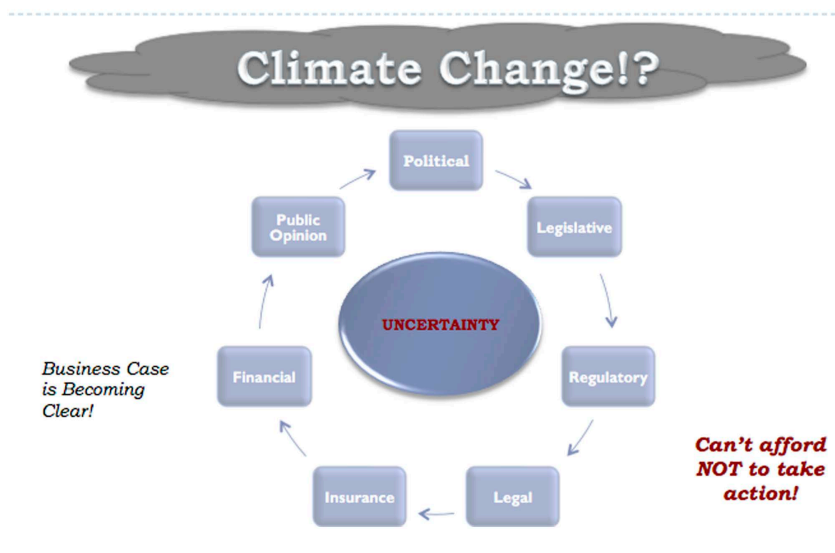

Figure 1. Corporate drivers for sustainability actions. 
recognizing that this would significantly reduce the risks and impacts of climate change..." 5

That ambition is the Paris Accord, which came on the heels of other failed attempts to pass binding treaties such as the 1992 Kyoto Protocol agreement ${ }^{6}$ [which recognized that developed countries are primarily responsible for high levels of GHG emissions in the atmosphere that these countries should have the largest burden (and cost) associated with cleaning the atmosphere, and that these burdens should be legally binding].

As Kelly and others have pointed out, the technologies needed to meet the objectives have not been invented yet. Even the most hard-core CC politicians recognize that massive economic disruption and lower standards of living will be required. To think their constituents would willingly accept the demands of leaders who will likely exempt themselves from paying the costs, to make sacrifices that citizens from other countries will not have to flies in the face of all that we know about human behavior. Wars have been fought over less. History shows that most politicians will do what they always do-kick the can down the road. I do not believe there will ever be a binding, and effective treaty, nor do I believe the world even needs one.

There are plenty of legitimate actions that are, and can be, taken to lower emissions, reduce energy consumption and increase efficiency without any treaty. Unquestionably these are the actions that will have the most positive, and measureable, impact today on global temperatures. Despite the lack of treaties, or even clear-cut direction, companies are taking action. But, more can be done as I point out below.

\section{Regulatory/legislative}

The U.S. government (executive branch) has already codified climate change into its actions and strategies, and most will be virtually impossible to overturn. CG is not a partisan political issue. It didn't suddenly become important when President Obama took office. Indeed, President G.W. Bush took the first big step with the 2008 National Intelligence Assessment (NIA), which classified climate change as a national security threat. ${ }^{7}$ That document set things in motion that Obama just reinforced with other executive actions. These orders led to regulatory changes (EPA, etc.), guidance documents and strategy changes.

Along with other orders, the NIA has led to monumental changes in the way the U.S. government conducts all of its business from energy and emissions reduction requirements, product labeling requirements, supply chain reporting, and more. It also had tremendous influence on DoD strategy. The federal government is the largest purchaser of supplies, including energy, in the world. These changes have had serious implications for government suppliers because these policies are beginning to apply to every supplier. This is one more way the private sector is pulled into action!

There have been some regulatory actions taken aimed at publically traded companies, the most important being the 2010 Securities and Stock Exchange (SEC) guidance on emissions reporting. ${ }^{8}$

There have also been a few pieces of Congressional legislation, including the often overlooked 2010 Food Safety
Modernization Act, ${ }^{9}$ and its country of origin labeling requirement and verification that food products are grown/raised in a manner that is consistent with U.S. law. Think what this could lead to.

Another important piece of national legislation pointing to a possible future action is the 2002 Terrorism Risk Insurance Act (TRIA) that created a federal "backstop" for insurance claims related to acts of terrorism. ${ }^{10}$ That law was driven hard by the insurance industry, and has been re-authorized several times. Some believe that a similar backstop will be needed for $C C$-related insurance claims-should they be proven.

\section{Insurance}

Insurance companies are some of the largest investors in real estate, and have enormous influence (and vested interest) over building codes, performance standards, benchmarking, emissions disclosure, etc. The EPA/DoE ENERGY STAR® Portfolio Manager ${ }^{11}$ has created a serious competitive challenge with building owners, real estate investment trusts, and more. Higher scores mean higher property values and rents. And, one cannot dismiss new insurance products that arise from these codes and standards.

\section{Financial}

The $\mathrm{SEC}^{12}$ is a government commission created by Congress that is charged with protecting investors, maintaining a fair and orderly function of the securities markets, and facilitating capital formation. The 2010 SEC Guidance document on emissions reporting has led to an explosion in the number of U.S. companies, public and private, publishing sustainability reports. It has also led to an increase in shareholder resolutions. Risk management at its best.

\section{Public opinion}

Public opinion has never been overwhelmingly in support of, or against, the concept of man-made climate change. But, in today's heated political environment it is important to recognize who are the shapers of public opinion (i.e., media and researchers chasing dollars). The media's influence is obvious. How can a researcher influence opinion? Simple really. As a former journalist myself I had to find sources for my stories. If $\mathrm{Al}$ Gore says the planet is melting, I need to find credible folks to tell me it is, or isn't. I owe that to my readers. Since those early days of climate science literally billions of (mostly) public dollars have been spent on climate research. Universities and research centers chase money to survive. If those who control the money claim CG is real the signal is very clear to researchers what they need to do. It's equally clear to reporters. As one, I would naturally call these researchers for information and quotes. And, if the researcher is media savvy all the better. Quotes make the story! Most reporters are, by nature, generalists. They do not know what questions to ask about complicated issues, and even less likely to know what the answers mean. So, if a researcher told me the earth was melting, and if she were media savvy and gave me the critical sound byte or quote I was searching for I'd use it. If someone questioned me I'd go back to 
that researcher or someone equally quotable (and likely to think similarly) to reinforce my original point. Oh, I'd acknowledge those who thought otherwise, but their facts and opinions would not be given equal billing.

The sad fact is that most reporters tend to think and act the same way, and that human nature transcends all professions. Unfortunately, it leads to groupthink, one point of view, hampers discovery, and dissenters are usually ostracized. It does not surprise me at all that the public has little trust in the media, politicians, and researchers when it comes to CC. Yet, most consumer research shows that people want sustainable goods and services. Companies know this.

\section{Legal}

Litigation is expensive, and just the threat is perhaps the most important driver for corporate action. Who wants to be sued twenty years down the road for something they did today? The SEC document referenced above certainly leaves the door open for future lawsuits-what may not be material today may be tomorrow. And, some high profile cases with far-reaching consequences have been heard throughout our court system. For a good summary of climate change litigation see the regularly updated litigation chart published by attorneys Arnold \& Porter Kaye Scholer. ${ }^{13}$

In normal situations all of these drivers would probably result in inaction. But, the CG issue is anything but normal. As I've pointed out, companies are taking action. These actions certainly fall under the risk management mantle, but I believe there is a simpler reason they take action-peer pressure.

\section{What actions do companies take?}

Perhaps some will claim that the free market is driving the two most popular company actions: sustainability reporting and implementing Energy Efficiency (EE) projects, but my experiences have convinced me that the primary reason for action is growing amount of peer pressure.

\section{Sustainability reporting}

To be clear, sustainability reporting efforts began long before it came into vogue, but the sheer numbers of companies annually submitting sustainability reports is staggering, and growing. These reports concern the social, economic, and environmental performance of a company. They used to be good public relations pieces, but they are far more than that now. There is no central convening authority that forces reporting, and the only legitimate explanation of the growing influence that peer pressure has on reporting is growing climate concerns and the lack of satisfaction with international efforts.

I believe that something truly remarkable came from the Paris meetings that led to the Accord: while governments did step up and submit INDCs stating how they intend to meet the objectives, the pendulum swung from the public sector (i.e., government) to the private sector. For the reasons stated earlier, the objectives of the Paris Agreement are impossible to meet, and represent a bridge too far for the governments who will be called upon to make the greatest sacrifices. Like all of these international climate meetings there was a very large private company presence in Paris, and the advocates for massive change to protect the climate are very savvy. These are the same people who were brilliant enough to irrevocably tie a company's environmental performance to its social and economic performance. For proof of their success I challenge the reader to investigate the side meetings where the advocates and large corporations, along with the Bill Gates of the world gather. One can find a great deal of information at the UN Framework Convention on Climate Change website under the Adaptation Private Sector Initiative (PSI) page. ${ }^{14}$

Organizations such as CERES, a U.S. based nonprofit whose mission is to "mobilize investor and business leadership to build a thriving sustainable global economy,"15 and Global Reporting Initiative (GRI), an independent organization that helps "businesses, governments and other organizations understand and communicate the impact of business on critical sustainability issues such as climate change, human rights, corruptions, and many others." 16 These organizations serve a valuable purpose, if for no other reason than to advance the peer pressure companies apply to each other to publish sustainability reports.

Increasingly, those companies who don't report are "named and shamed," which forces more compliance. There's certainly value in filing reports, as pointed out in numerous publications. Ernst \& Young and the Boston College Center for Corporate Citizenship published a paper in October 2016 outlining the history of sustainability reporting, the value of such reports, and the likely future of reporting. In summary, the paper found that sustainability reporting has emerged as a common business practice of 21 st-century business. Some of the ways that sustainability reporting has provided value to those companies who do report include: improved reputation; reduced amount of inaccurate information about performance; helped the organization refine its vision or strategy; improved relationship with regulatory bodies and shareholders, led to waste reduction and other forms of savings within the organizations. ${ }^{17}$

There are a number of reporting frameworks being used by companies who do file sustainability reports. The Global Reporting Initiative (GRI) is the most widely used, with over 5000 companies worldwide using its framework. But there are others as well, and now an effort is underway to synchronize and simplify. I do not have the space for a deeper dive on the nuances of reporting other than to say there are many, some are demanding third-party verification, and they are in-depth and very expensive. And, they have all but led to the demise of "green-washing."

I am most familiar with the energy-related reporting demands, and have assisted many large national and international corporations with completing worksheets that eventually are incorporated into their sustainability report. The energyrelated worksheets wanted to know the amount and source of power purchased, and the related emissions from the generation sources. The amount of power purchased for operations is fairly easy to obtain - even if it for a couple of floors in a 50-story 
building that does not have good submetering practices. However, once power is generated and put onto the transmission and electric grid it is impossible to determine its source-even if it is from renewable energy. To complete the questionnaires a lot of assumptions must be made.

I recall one prospective client that I was called in by the sales person to help convince him to leave his current supplier and move his business to us. His company purchased about $\$ 50$ million worth of power annually throughout the U.S. He was by far the most interesting buyer I ever dealt with because he was also the company's sustainability officer. I have not run into such a person since, and unlikely to because those roles require different skills and attitudes, and attract different personalities. [Remember, they rarely talk to each other.]

I knew it would be very tough to beat his current provider's price, but that wasn't his main concern. He wanted to know how clean our generation fleet was, and if we were cleaner than his current provider we'd get the business. Like most large providers we owned a large fleet of generation plants (some coal, some gas, and even a few renewable energy plants). As I stated earlier, once the power is on the grid you cannot determine its source. To make matters worse we, like most of our competitors, also bought power off the market from other generators. I explained this to him and he said he understood, but by giving him our fleet average I "was giving him something to hang his hat on." We didn't win his business, but it sure was an eye-opening experience that I am positive most providers go through-or soon will-because of sustainability reporting.

To provide an indication of the future of reporting - and the increasing peer pressure-the reader needs to look no further than the 2009 UN-backed Sustainable Stock Exchange (SSE) initiative, "a peer-to-peer learning platform for exploring how exchanges, in collaboration with investors, regulators, and companies, can enhance corporate transparency-and ultimately performance-on environmental, social and corporate governance (ESG) issues and encourage sustainable investment." By 2012, five of the world's 82 stock exchanges had become Partner Exchanges, whereby they voluntarily make a public commitment to promote improved ESG disclosure and performance among listed companies. [Listed companies must report their sustainability actions or explain why they are not taking any such action.] By the end of 2016 there were 62 such Partner Exchanges, representing nearly $70 \%$ of global market capitalization. Of the 62 Partner Exchanges, 20 have developed their own guidance on ESG reporting (up 13 in one year), and 12 require listed companies to incorporate ESG information into their listing rules, and another 15 are providing formal guidance to assist listed companies in preparing their ESG reports. ${ }^{18}$ The NASDAQ and other U.S. stock exchanges are considering adopting this voluntary effort. Peer pressure works!

The 2010 Securities and Commission (SEC) interpretive guidance document reiterates longstanding regulations that U.S. companies must address in their public filings "material risks or opportunities." That document singles out four types of risks that may be material: (i) impact of legislation and regulation; (ii) impact of international accords; (iii) indirect consequences of regulation or business trends; and (iv) risks posed by the physical impacts of CC. These risks are documented in annual $(10 \mathrm{~K})$ reports under Management Discussions.

Corporate lawyers, officers, and investors have struggled with this because of the lack of clear definitions. For instance, how do you define indirect consequences of CC? The SEC document did seek to clarify indirect costs as "decreased demands for goods that produce significant GHG emissions; increased demands for goods that result in lower emissions; increased competition to develop innovative new products." It also includes the reputational risk companies face. How do you quantify this? You can't, but they report anyway!

How serious are companies taking this reporting guidance? From the SEC document: "Information is material and must be disclosed if there is a likelihood that a reasonable investor would consider it important in deciding how to vote or make an investment decision." Interpreting that clause makes it easy to see how important the rise of shareholder resolutions, and legal challenges are.

I already mentioned the U.S. government actions regarding suppliers. To take it a step further that every federal agency has to report their Scope 1, 2, and 3 emissions, along with their energy use. They were mandated to develop, implement and report annually on the actions that they must take to meet Federal objectives. To drive home its impact on the private sector one must understand what Scope 1, 2, and 3 emissions are, and how they impact companies. ${ }^{19}$

Simply put, Scope 1 emissions are direct emissions, those that occur onsite or from sources that companies own and/or control such as every energy consuming device in their buildings, along with their vehicle fleets.

Scope 2 emissions are indirect emissions that result from the generation of the electricity, heat or steam that companies purchase. Energy providers are typically asked to help determine this number, and I assisted many companies with these calculations. If you are a Federal agency required to reduce emissions you want to purchase the "cleanest" energy available. This impacts suppliers.

Scope 3 emissions include employee travel and supply chain emissions. Studies show that over $50 \%$ of the average company's carbon emissions are from their suppliers. This forces the most costly actions associated with reporting (including EE efforts, etc.) to be taken by suppliers.

Some people refer to supply chain reporting as the Wal-Mart effect as it was one of the earliest multinational companies to adopt it. Simply put, buyers have the right to inspect supplier's manufacturing and distribution facilities to ensure compliance. I believe this alone has more impact and authority than any international treaty can ever have. It's pay-to-play, pure and simple, and it's the result of peer pressure.

You see where this is going. If governments cannot pass enforceable, meaningful treaties, laws and regulations, and the perceived problem is seen as enormously complicated and expensive (by many), the best path forward is to bring the private sector in as a willing or unwilling partner. Naming and shaming has long been effective in forcing company actions.

I recall a study an ex-employer (energy consulting firm) did concerning Japanese business. It was in the early $2000 \mathrm{~s}$. 
Realize that Japan has no domestic energy supplies. It imports virtually all of its nonrenewable energy. The government has "encouraged" companies to lower their energy use through the years, largely via energy efficiency programs. These programs have been very successful. However, the most important influencer of corporate action was the threat of being publically identified as a noncomplier. Name and shame works!

The entire sustainability effort is complicated and farreaching, which is why there have been organized efforts by many organizations such as Ceres, and others. It is also a moneymaker for compliance-related companies. Given that, it's not difficult to see the direction sustainability is going-toward comprehensive supply chain reporting. Once this has been widely adopted-and I believe it is closer than most people imagine-the task of bringing/forcing the private sector into replace government action is complete. There is no turning back.

There are consequences to this, including a major disruption in how all suppliers conduct business. It is obviously tougher for small companies to meet such requirements, and supplier business models are necessarily changing. An example of this is the way energy companies sell power to their customers. In a highly competitive environment found in deregulated markets where the product (i.e., electricity) is distinguished by price alone, companies have no incentive to sell less of their product, and little understanding of what their customers want. Their industry is necessarily evolving from simply being a supplier to being a trusted energy advisor that has the products and services customers need to meet their sustainability goals. This is a disruptive business model that many companies in an industry that historically has not been innovative will not survive.

There are unintended consequences such as the cost to small companies often owned by minorities that provide services to these large companies that are supposed to support locallyowned companies through their sustainability efforts (i.e., the social aspect pillar). By the way, the Paris Accord has fully embraced the human aspect of meeting its objective while reducing poverty and not impacting food production.

There is also a massively disruptive phenomena occurring-that is, the switch from brick and mortar companies (i.e., large physical properties) to Internet purchasing. Some people refer to this as the "Amazon effect." It is not clear what kind of impact sustainability efforts will have on these companies, but one can rest assured that supply chain reporting will become even more important to companies who supply the goods to these Internet companies.

\section{Energy efficiency projects}

I believe the most positive thing to come from sustainability reporting is the more rapid adoption of energy efficiency (EE) projects. EE projects are the most effective sustainability action companies can take. They lower energy consumption and operating costs, reduce emissions, and increase operational efficiency. If done properly, EE projects can provide a competitive advantage. Most importantly, EE projects result in measureable mitigation actions. There is simply no greater action that consumers can do-today-that will actually combat CC. But, it hasn't been an easy road for the EE industry.
Historically, EE projects such as lighting or HVAC retrofits have had to compete against other projects for scarce dollars. They must meet an internal rate of return (IRR)-some people call it a "hurdle rate"-that result in a maximum payback ranging from 18 months to five years, with most falling into the three years return. A return greater (or longer) than the internal hurdle rate almost universally meant that the project would not be built. My customers and I had many EE projects not built because they could not meet the hurdle rate.

The rise of sustainability departments has been a great boon to the EE industry. Why? EE impact is measured by energy intensity, which is the amount of energy used per unit of gross domestic product (GDP). That's easy to measure. According to the International Energy Agency, Global energy intensity improved 1.8\% in 2015, after a 1.5\% improvement in 2014. Even more impressive is that the rate of improvement for each year of the prior decade was only $0.6 \%$. Overall, the 2016 IEA report on energy efficiency found that IEA countries saved an average of $\$ 490$ (USD) per capita, and a total of $\$ 540$ billion (USD) in energy expenditure in 2015 as a result of energy efficiency improvements since 2000. Avoided greenhouse gas (GHG) emissions totaled 1.5 billion tons of carbon dioxide $\left(\mathrm{GtCO}_{2}\right)$ in 2015 and $13 \mathrm{GtCO}_{2}$, cumulatively, since 2000. Energy efficiency avoided over $\$ 1$ trillion (USD) in investment in electricity generation. ${ }^{20}$

For those of us on the ground promoting and developing EE projects began to see more projects being built, and not necessarily because of the hurdle rate has been cleared. Rather, the bright light that the sustainability movement has shown on operations suddenly illuminated boardrooms. There were now additional advantages for EE projects, not the least of which was peer pressure and competitive advantage. One other benefit the sustainability effort had on EE-it virtually eliminated green-washing, the practice of claiming to be green through advertising and promotion, rather than actually implementing sustainable practices. Today, if a company truly wants to be identified as being sustainable, it has to adopt some sort of reporting mechanism that must be independently verified by a third party.

Being prudent risk managers and good corporate stewards can add an indeterminate amount of value to a company, but that alone is not enough to drive investment in projects that are not considered prudent or financially sound. One must consider that within each company there are competing interests for a limited set of dollars. Reporting and EE investments are occurring primarily because of peer pressure, and that will only accelerate moving forward; its too ingrained; affordable (compared to the alternative); and the PR value can be immense.

\section{Conclusion}

As Krane points out, there are risks to energy companies associated with climate change. But, realistically, no company is exempt from similar risks, as I have described above. All inputs required for company operations are being scrutinized, especially energy because it is in every company's supply chain. 
Table 1. The table above is a partial list of executive orders, policies and strategies, and more aimed at reducing the U.S. emissions. Some are likely to be overturned, but others are already implemented, provide benefits, and are not likely to be overturned. The foundational international document is the 2007 UN International Panel on Climate Change report, which does present problems for many people. Links to most of these actions can be found at: http://www. globalchange.gov/browse/federal-adaptation-resources/executive-orders-and-policies.

\begin{tabular}{|c|c|c|c|}
\hline $\begin{array}{l}\text { Executive orders/ } \\
\text { policy/updates/laws }\end{array}$ & Date & Title & Action \\
\hline Policy & 2008 & $\begin{array}{l}2008 \text { National Intelligence } \\
\text { Assessment on the National } \\
\text { Security Implications of } \\
\text { Global Climate Change to } \\
2030\end{array}$ & $\begin{array}{l}\text { Initial document identifying CC as a national security threat in } \\
\text { six ways: (i) threats to the stability of countries; (ii) heightened } \\
\text { social and political tensions; (iii) adverse effects on food } \\
\text { prices and availability; (iv) increased risks to human } \\
\text { health; (v) negative impacts on investments and economic } \\
\text { competitiveness; (vi) potential climate discontinuities and } \\
\text { secondary surprises }\end{array}$ \\
\hline 13514 & 0ct-09 & $\begin{array}{l}\text { Federal Leadership in } \\
\text { Environmental, Energy, \& } \\
\text { Economic Performance }\end{array}$ & $\begin{array}{l}\text { Set sustainability goals for Federal agencies and focused on } \\
\text { making improvements to their environmental, energy, and } \\
\text { economic performance }\end{array}$ \\
\hline 13547 & Jun-10 & $\begin{array}{l}\text { Stewardship of the Ocean, } \\
\text { Our Coasts, \& the Great } \\
\text { Lakes (also known as the } \\
\text { National Ocean Policy) }\end{array}$ & $\begin{array}{l}\text { To ensure the protection, maintenance, and restoration of the } \\
\text { health of ocean, coastal, and Great Lakes ecosystems and } \\
\text { resources; enhance the sustainability of ocean and coastal } \\
\text { economies; and coordinate with national security and foreign } \\
\text { policy interests }\end{array}$ \\
\hline SEC & Jan-10 & SEC Guidance Document & $\begin{array}{l}\text { Material risks and opportunities related to CC must be included } \\
\text { in corporate public filings. }\end{array}$ \\
\hline Policy & 2010 & $\begin{array}{l}2010 \text { National Security } \\
\text { Strategy }\end{array}$ & $\begin{array}{l}\text { To transform the way the U.S. uses energy_-diversifying supplies, } \\
\text { investing in innovation, and deploying clean energy technologies. } \\
\text { This will enhance energy security, create jobs, and fight climate } \\
\text { change. Additional DoD strategy documents have been drafted } \\
\text { reiterating national security risks associated with CC }\end{array}$ \\
\hline Law & Jan-11 & $\begin{array}{l}\text { Food Safety Modernization } \\
\text { Act }\end{array}$ & $\begin{array}{l}\text { Title III Section } 301 \text { Foreign Supplier Verification Program, } \\
\text { mandates that food importers perform risk-based activities } \\
\text { for the purposes of verifying that the food it imports is } \\
\text { produced in compliance with U.S. law. }\end{array}$ \\
\hline Policy & Jun-13 & $\begin{array}{l}\text { The President's Climate } \\
\text { Action Plan }\end{array}$ & $\begin{array}{l}\text { A comprehensive plan for action to cut carbon pollution, } \\
\text { prepare the Nation for the impacts of climate change, and } \\
\text { lead international efforts to address climate change as } \\
\text { a global challenge }\end{array}$ \\
\hline 13653 & Nov-13 & $\begin{array}{l}\text { Preparing the United States } \\
\text { for the Impacts of Climate } \\
\text { Change }\end{array}$ & $\begin{array}{l}\text { Directs Federal agencies to take a series of steps to make it } \\
\text { easier for American communities to strengthen their resilience } \\
\text { to climate change. Recommendations delivered July, } 2015\end{array}$ \\
\hline 13677 & Sep-14 & $\begin{array}{l}\text { Climate-Resilient } \\
\text { International Development }\end{array}$ & $\begin{array}{l}\text { Requires agencies to factor climate-resilience considerations } \\
\text { systematically into the U.S. Government's international } \\
\text { development work and to promote a similar approach with } \\
\text { multilateral entities }\end{array}$ \\
\hline
\end{tabular}


Table 1. Continued

\begin{tabular}{|c|c|c|c|}
\hline $\begin{array}{l}\text { Executive orders/ } \\
\text { policy/updates/laws }\end{array}$ & Date & Title & Action \\
\hline 13690 & Jan-15 & $\begin{array}{l}\text { Establishing a Federal Flood } \\
\text { Risk Management Standard } \\
\text { and a Process For Further } \\
\text { Soliciting and Considering } \\
\text { Stakeholder Input }\end{array}$ & $\begin{array}{l}\text { To reduce the risk and cost of future flood disasters by requiring } \\
\text { all Federal investments in and affecting floodplains to meet } \\
\text { higher flood risk management standards }\end{array}$ \\
\hline GA0 report $15-290$ & Feb-15 & $\begin{array}{l}\text { GA0 Report to Congress: } \\
\text { High Risk Series, } \\
\text { An Update }\end{array}$ & $\begin{array}{l}\text { This is a biennial update by the Government Accountability } \\
\text { Office (GA0) that identifies high-risk areas needing attention } \\
\text { by Congress and the Executive branch. This report seeks to } \\
\text { limit the Federal Government's fiscal exposure by better } \\
\text { managing Climate Change risks }\end{array}$ \\
\hline 13693 & Mar-15 & $\begin{array}{l}\text { Planning for Federal } \\
\text { Sustainability in the } \\
\text { Next Decade }\end{array}$ & $\begin{array}{l}\text { Cut the Federal Government's greenhouse gas (GHG) emissions } \\
40 \% \text { over the next decade, relative to } 2008 \text { levels. Also calls } \\
\text { for each agency to develop and implement a Strategic } \\
\text { Sustainability Plan continuing through fiscal year 2025. Also } \\
\text { calls for an annual release of Federal Supplier Greenhouse Gas } \\
\text { Management Scorecard identifying suppliers who have and } \\
\text { have not publically disclosed GHG emissions data }\end{array}$ \\
\hline Progress report & Jul-15 & $\begin{array}{l}\text { Progress Report Highlighting } \\
\text { Federal Actions Addressing } \\
\text { the Recommendations } \\
\text { from E0 } 13653\end{array}$ & $\begin{array}{l}\text { Highlights actions taken to remove barriers to improving } \\
\text { Resilience to communities, nation's infrastructure, natural } \\
\text { resources, population, climate smart mitigation and recovery, } \\
\text { understanding economics of resilience, and U.S. Climate } \\
\text { Resilience Toolkit }\end{array}$ \\
\hline Policy & 2015 & Clean Power Plan & $\begin{array}{l}\text { This is the major U.S. effort to reach the target highlighted in the } \\
\text { Paris Agreement }\end{array}$ \\
\hline
\end{tabular}

For the reasons I've outlined above (and more) it is clear that sustainability efforts are not going away, regardless of which party is in power in the United States or any other country. If anything, these efforts will accelerate. As they become more ingrained in the daily operations of all companies-primarily through peer pressure-they will, collectively, become more powerful than any international treaty, and something that cannot easily be removed (Table 1 ).

\section{NOTES AND REFERENCES:}

1. Kelly M.: (2016). Lessons from technology development for energy and sustainability. MRS Energy \& Sustainability, 3. doi:10.1557/ mre.2016.3.

2. U.S. Environmental Protection Agency: Climate Change Definition. Available at: https://www.epa.gov/climatechange/climate-change-basicinformation (accessed February 25, 2017).

3. United Nations: The World Commission on Environment and Development (Brundtland Commission) (1987). Available at: http://www.un-documents. net/our-common-future.pdf (accessed January 12, 2017).

4. United Nations: World Summit on Social Development (2005). Available at: http://www.un.org/en/events/pastevents/worldsummit_2005.shtml (accessed January 12, 2017).
5. United Nations: Paris Agreement (2015). Available at: http://unfccc.int/ files/essential_background/convention/application/pdf/english_paris_ agreement.pdf (accessed January 12, 2017).

6. United Nations Framework Convention on Climate Change (1992). Available at: http://unfccc.int/kyoto_protocol/items/2830.php (accessed February 16, 2017).

7. Fingar T.: Statement for the Record: National Intelligence Assessment on the National Security Implications of Global Climate Change to 2030 (2008).

8. U.S. Securities and Exchange Commission: Commission Guidance Regarding Disclosure Related to Climate Change (2010). Available at: https://www.sec.gov/rules/interp/2010/33-9106.pdf (accessed January 10, 2017).

9. U.S. Food \& Drug Administration: FDA Food Safety Modernization Act (2011). Available at: http://www.fda.gov/Food/GuidanceRegulation/ FSMA/ (accessed January 10, 2017).

10. U.S. Department of the Treasury: Terrorism Risk Insurance Program (2002). Available at: https://www.treasury.gov/resource-center/fin-mkts/ Pages/program.aspx (accessed January 10, 2017).

11. U.S. Government: Energy Star Portfolio Manager ${ }^{\circledR}$. Available at: https://www.energystar.gov/buildings/facility-owners-and-managers/ existing-buildings/use-portfolio-manager (accessed January 12, 2017).

12. U.S. Securities and Exchange Commission. Available at: https://www.sec. gov/about/whatwedo.shtml (accessed February 22, 2017). 
13. Arnold \& Porter Kay Scholar: Climate Change Chemical Legislation (2017). Available at: http://www.apks.com/ /media/files/climatechangechemicallegislation/climatechangelitigationchart.pdf (accessed January 12, 2017).

14. United Nations: Framework Convention on Climate Change. Adaptation Private Sector Initiative (PSI). Available at: http://unfecc.int/adaptation/ workstreams/nairobi_work_programme/items/4623.php (accessed February 24, 2017).

15. Ceres. Available at https://www.ceres.org (accessed February 26, 2017).

16. GRI. Available at https://www.globalreporting.org (accessed March 27, 2017).
17. Ernst \& Young: Value of Sustainability Reporting (2016). Available at: http://www.ey.com/Publication/vwLUAssets/EY_-_Value_of_sustainability_ reporting/\%24FILE/EY-Value-of-Sustainability-Reporting.pdf (accessed February 24, 2017).

18. UN Sustainable Stock Exchange (SSE) Initiative. Available at: http://www. sseinitiative.org/ (accessed February 23, 2017).

19. Greenhouse Gas Protocol: About the GHG Protocol (2001). Available at: http://www.ghgprotocol.org/about-ghgp (accessed January 31, 2017).

20. International Energy Agency: Energy Efficiency Market Report 2016. Available at: www.iea.org (accessed February 22, 2017). 